\title{
TOTAL PHENOLIC CONTENT AND IN VITRO ANALYSIS OF ANTIOXIDANT, ANTIBACTERIAL, AND ALPHA-GLUCOSIDASE INHIBITION PROPERTIES OF CHROOCOCCUS MINUTUS (KÜTZING) NÄGELI (CHROOCOCCALES, CYANOBACTERIA)
}

\author{
CHROOCOCCUS MINUTUS (KÜTZING) NÄGELI'NIN (CHROOCOCCALES, \\ CYANOBACTERIA) ANTIOKSIDAN, ANTIBAKTERIYYL VE ALFA-GLUKOZIDAZ \\ INHIBISYON ÖZELLIKLERININ TOPLAM FENOLIK ICCERİĞİ VE IN VITRO ANALIZİ
}

Eldrin DLR. ARGUELLES ${ }^{1 *}$

${ }^{1}$ University of the Philippine Los Baños, Philippine National Collection of Microorganisms (PNCM), National Institute of Molecular Biology and Biotechnology (BIOTECH), 4031, Laguna, Philippines

\begin{abstract}
Objective: Cyanobacteria are novel sources of bioactive substances with important biological activities. In this study, the total phenolic content (TPC) and bioactive (antioxidant, antidiabetic, and antibacterial) properties of a freshwater cyanobacteria, Chroococcus minutus were investigated.

Material and Method: Methanol extract of $C$. minutus were prepared and subjected to different biological assays to determine the TPC, antioxidant, and alpha-glucosidase inhibition properties. The antibacterial activity was done using microtiter plate dilution assay against various medically important bacterial pathogens.

Result and Discussion: C. minutus has a TPC of $11.27 \pm 0.14 \mathrm{mg}$ GAE/g. Antioxidant efficiency of C. minutus are characterized by having potent DPPH scavenging activity with $I_{50}$ value of $255 \mu \mathrm{g} / \mathrm{ml}$. Assessment of alpha-glucosidase inhibition property showed that $C$. minutus extract have potent inhibition activity with $I_{50}$ of $5.50 \mu \mathrm{g} / \mathrm{ml}$ as compared to acarbose (standard antidiabetic drug). In addition, $C$. minutus extract exhibited potent antibacterial activities against Bacillus cereus, Listeria monocytogenes, and Methicillin-resistant Staphylococcus aureus. The current investigation shows the potential of C. minutus as source of active metabolites with important use in pharmaceutical applications.
\end{abstract}

Keywords: Biological activity, cyanobacteria, freshwater, Philippines

ÖZ

\footnotetext{
* Corresponding Author/Sorumlu Yazar: Eldrin DLR. Arguelles

e-mail / e-posta: edarguelles@ up.edu.ph, Phone / Tel.: +63495362721
} 


\begin{abstract}
Amaç: Siyanobakteriler, önemli biyolojik aktivitelere sahip yeni biyoaktif madde kaynaklarıdır. Bu çalışmada, bir tatlu su siyanobakterisi olan Chroococcus minutus'un toplam fenolik içeriği (TPC) ve biyoaktif (antioksidan, antidiyabetik ve antibakteriyel) özellikleri incelenmiştir.

Gereç ve Yöntem: C. minutus'un metanol özütü hazırlanarak, TPC, antioksidan ve alfa-glukozidaz inhibisyon özelliklerini belirlemek için farklı biyolojik deneylere tabi tutulmuştur. Antibakteriyel aktivite, tıbbi açıdan önemli çeşitli bakteriyel patojenlere karşı mikrotitre plaka seyreltme deneyi kullanılarak yapılmıştır.

Sonuç ve Tartışma: $C$. minutus'un TPC'si $11.27 \pm 0.14 \mathrm{mg}$ GAE $/ \mathrm{g}^{\prime}$ dir. C. minutus'un antioksidan etkinliği, $255 \mu \mathrm{g} / \mathrm{ml} \mathrm{IC} C_{50}$ değeri ile güçlü DPPH temizleme aktivitesine sahip olmaslyla karakterize edilir. Alfa-glukozidaz inhibisyon özelliğinin değerlendirilmesi, C. minutus özütünün, akarboza (standart antidiyabetik ilaç) klyasla $5.50 \mu \mathrm{g} / \mathrm{ml}$ IC $C_{50}$ ile güçlü inhibisyon aktivitesine sahip olduğunu gösterdi. Ek olarak, C. minutus özütü, Bacillus cereus'a, Listeria monocytogenes'e ve Metisiline dirençli Staphylococcus aureus'a karşı güçlü antibakteriyel aktiviteler sergilemişstir. Mevcut araştırma, farmasötik uygulamalarda önemli kullanımı olan aktif metabolitlerin kaynağı olarak C. minutus'un potansiyelini göstermektedir.
\end{abstract}

Anahtar kelimeler: Biyolojik aktivite, siyanobakteriler, tatl su, Filipinler

\title{
INTRODUCTION
}

Cyanobacteria have notable attractiveness as novel sources of bioactive substances with diverse biological activities (antioxidant, antimicrobial, antidiabetic, anti-inflammatory, and antiviral effects) [1,2]. Several strains of cyanobacteria (Oscillatoria limnosa, Anabaena, and Synechocystis aquatilis) were reported to show antibacterial activities against Bacillus subtilis, B. thuringensis, B. megaterium, Escherichia coli, Pseudomonas aeruginosa, and Candida tropicalis [1,3]. These reported activities are associated with various intracellular and extracellular metabolites that are produced by several strains of cyanobacteria with known diverse biological activities [3]. Even though the chemical composition of the bioactive metabolites in cyanobacterial extract vary, the mechanism of action of these metabolites are usually similar, namely via photosystem II mediated electron flow inactivation of other organisms such as algae and bacteria. These allelopathic metabolites may serve an important role in species dominance and succession in nature [4]. One popular example of this substance is cyanobacterin which was isolated in Scytonema hofmanni and are reported to be toxic to cyanobacteria and a variety of eukaryotic algae.

Several species of cyanobacteria produce diverse kinds of secondary metabolites with antioxidants and antidiabetic properties. Previous studies show the isolation of several bioactive compounds from various cyanobacterial species such as flavonoids, protocatechuic acid, phycobiliproteins, gallic acids, chlorogenic acids, and catechin. These compounds are considered to have potent antioxidant and antidiabetic properties that can be tapped as novel alternative source of active substances for drug synthesis [1,5,6]. Cyanobacteria are considered reliable source of novel natural bioactive metabolites, since these organisms can be mass propagated in small and big bioreactors for large scale production. In addition, the growth characteristic of the cyanobacterial cells can be manipulated and controlled, so that no toxic substances will be included in the harvested algal biomass $[1,6]$. 
Cyanobacteria with high growth rate and novel bioactive metabolites have yet to be studied and exploited for pharmaceutical purposes, and isolation and characterization of algal strains with potential for pharmaceutical application remain the focus of continuing research [1,3,5]. Given these promising benefits which can be obtained from cyanobacteria, it is necessary to explore the potential of local species to produce bioactive compounds. Thus, the current study was conducted to determine total phenolic content and evaluate the antioxidant, antibacterial, and antidiabetic (using $\alpha$-glucosidase inhibition assay) properties of a freshwater cyanobacteria, Chroococcus minutus.

\section{MATERIAL AND METHOD}

\section{Chemicals}

The chemicals used were of analytical grade and obtained from Sigma-Aldrich (Singapore City, Singapore). On the other hand, the solvents used were of analytical and HPLC grade and were obtained from Sigma-Aldrich (Steinheim, Germany, and Singapore City, Singapore) or Merck (Darmstadt, Germany).

\section{Cyanobacterial Culture and Cultivation}

The cyanobacteria, $C$. minutus were obtained from PNCM-BIOTECH of the University of the Philippines Los Baños. Initially, C. minutus culture $(100 \mathrm{ml})$ was inoculated into three one liter sterile flasks containing BG 11 medium [2]. The mass cultivation set up run for 14 days under light condition (fluorescent white lamps with light intensity of $120 \mu \mathrm{mol}$ photons $\mathrm{m}^{-2} \mathrm{~s}^{-1}$ ) and incubated at a mean temperature of $23 \pm 2{ }^{\circ} \mathrm{C}$. The cyanobacterial biomass was harvested via centrifugation set at 10,000 rpm for $10 \mathrm{~min}$. The algal pellet was rinsed several times with sterile water and freeze-dried using a lyophilizer (Virtis Freeze mobile 25 SL) [2].

\section{Preparation of Cyanobacterial Extract}

Dried and pulverized biomass of C. minutus (1 gram) was subjected to extraction using $20 \mathrm{ml}$ methanol in an ultrasonic bath for 30 minutes with continuous stirring for $1 \mathrm{hr}$. The sample mixture was concentrated (via centrifugation) at $12,000 \mathrm{rpm}$ for $20 \mathrm{~min}$ at a temperature of $20^{\circ} \mathrm{C}$. The algal extract was further concentrated using a rotary evaporator set at $40{ }^{\circ} \mathrm{C}$ under reduced pressure. The concentrated algal extract was kept under refrigerated condition $\left(4^{\circ} \mathrm{C}\right)$ to preserve its biological activity for use to different biological assays needed in the study $[2,6]$.

\section{Determination of total phenolic content (TPC)}

The TPC of $C$. minutus was determined following the method proposed by Nuñez-Selles et al. [7]. Initially, about $0.5 \mathrm{ml}$ of $C$. minutus crude extract was mixed with $0.5 \mathrm{ml} 10 \%$ sodium carbonate solution and $0.5 \mathrm{ml}$ of Folin-Ciocalteau's reagent for 1 minute. The sample mixture was allowed to stand for 5 minutes at ambient temperature. Furthermore, the volume of the sample mixture was adjusted 
using $5 \mathrm{ml}$ sterile distilled water. Absorbance reading of all the sample mixture was measured at 720 $\mathrm{nm}$ using an Ultraviolet-Visible spectrophotometer (Shimadzu, Kyoto, Japan). The TPC is presented as microgram of gallic acid equivalent (GAE) per gram of the algal extract (calibration curve equation: $y$ $\left.=0.0682 \mathrm{x}-0.0214, \mathrm{r}^{2}=0.997\right)[2,7]$.

\section{2,2-Diphenyl-1-picrylhydrazyl (DPPH) Radical Scavenging Assay}

The radical scavenging effect against DPPH of the $C$. minutus extract was analyzed using the methods done by Ribeiro et al. [8]. Briefly, $5.0 \mathrm{ml}$ of $0.1 \mathrm{mM}$ DPPH solution was mixed with $100 \mu \mathrm{l}$ of the $C$. minutus extract. The reaction mixture was mixed (via vortex mixer) and was kept at ambient temperature for 20 minutes. The absorbance readings of the different $C$. minutus extract concentrations and the controls were taken at $517 \mathrm{~nm}$ wavelength using a UV-VIS spectrophotometer. The scavenging inhibition activity (\%) was computed using the equation:

$$
\text { Inhibition }(\%)=\left(\frac{A_{\text {control }}-A_{\text {sample }}}{A_{\text {control }}}\right) \times 100
$$

where: $\mathrm{A}_{\text {control }}=$ absorbance reading of the control $\left(\mathrm{DPPH}\right.$ solution without algal sample) and $\mathrm{A}_{\text {sample }}=$ absorbance reading of the algal extract sample (DPPH solution with test sample). Ascorbic acid was used as the control in this assay. The effective concentrations $\left(\mathrm{IC}_{50}\right)$ of the control antioxidant and $C$. minutus extract needed to nuetratlize 50\% of DPPH radicals were determined using the standard curve generated from the scavenging activities of different concentrations of the algal extract $[8,2]$.

\section{Antibacterial Activity}

Three Gram-negative bacteria (Aeromonas hydrophila BIOTECH 10089, Pseudomonas aeruginosa BIOTECH 1824, and Escherichia coli BIOTECH 1634) and three Gram-positive bacteria (Bacillus cereus BIOTECH 1509, Listeria monocytogenes BIOTECH 1958, and Methicillin-Resistant Staphylococcus aureus BIOTECH 10378) were tested against $C$. minutus crude extract using microtiter plate dilution assay. These reference pathogens were obtained from PNCM, BIOTECH-UPLB. The bacterial strains used in this study are known bacterial pathogens reported in the Philippines causing diseases such as listeriosis, gastroentiritis, food poisoning, cellulitis, sepsis, and urinary tract infections (Table 1) [9]. Thus, the antibacterial assay was done to assess the effectivity of the algal extract against these medically-important bacterial pathogens. Initially, bacterial pathogens were pre-cultivated using Luria Bertani broth medium and incubated at with shaking for 24 hours at $37^{\circ} \mathrm{C}$. Purity and viability of each test organisms were regularly monitored by conducting regular biochemical tests and morphological characterization [2,9]. Microtiter plate dillution (two-fold serial dilution technique) assay was used to determine the antibacterial activities of $C$. minutus extract [2,9]. Briefly, $100 \mu$ of broth cultures of the bacterial pathogens (cell density of $1 \times 10^{6} \mathrm{cells} / \mathrm{ml}$ ) were gently mixed with $100 \mu \mathrm{l}$ of $C$. 
minutus extract set at different dilutions $\left(1, \frac{1}{2}, \frac{1}{4}, \frac{1}{8}, \frac{1}{16}, \frac{1}{32}, \frac{1}{64}\right.$, and $\frac{1}{128}$ of algal crude extract concentrations). The antibacterial assay was done in triplicates and were incubated for 12 hours in an incubator set at $35^{\circ} \mathrm{C}$. After incubation, antibacterial activity of $C$. minutus extract against different bacterial pathogens were taken $[2,9]$.

Table 1. Bacterial pathogens used in the assay and their respective pathogenicity

\begin{tabular}{|l|l|}
\hline Bacterial Pathogen & Pathogenicity (Diseases) \\
\hline Gram-positive bacteria & \\
\hline $\begin{array}{l}\text { Bacillus cereus } \\
\text { BIOTECH 1509 }\end{array}$ & $\begin{array}{l}\text { Food poisoning and gastrointestinal illness: emetic } \\
\text { (vomiting) syndrome and the diarrhoeal syndrome }\end{array}$ \\
\hline $\begin{array}{l}\text { Listeria monocytogenes } \\
\text { BIOTECH 1958 }\end{array}$ & Causes listeriosis \\
\hline $\begin{array}{l}\text { Methicillin-Resistant } \\
\text { Staphylococcus aureus BIOTECH } \\
\text { 10378 }\end{array}$ & Food poisoning and infection in hospitals \\
\hline Gram-negative bacteria & $\begin{array}{l}\text { Generalized inflammation } \\
\text { and sepsis }\end{array}$ \\
\hline $\begin{array}{l}\text { Pseudomonas aeruginosa } \\
\text { BIOTECH 1824 }\end{array}$ & $\begin{array}{l}\text { Gastroentiritis in humans; } \\
\text { ulcers, tail rot, fin rot and hemorrhagic septicemia in fish }\end{array}$ \\
\hline BIOTECH 10089 & Gastrointestinal and urinary tract infection \\
\hline $\begin{array}{l}\text { Escherichia coli } \\
\text { BIOTECH 1825 }\end{array}$ & \\
\hline
\end{tabular}

\section{a-Glucosidase Inhibition Assay}

The ability of $C$. minutus extract to inhibit $\alpha$ - glucosidase was assessed by spectrophotometric assay using $p$-nitrophenyl- $\alpha$-glucopyranoside ( $p N P G$ ) following the methods of Nair et al. [10]. The presence of $\alpha$-glucosidases in algal extract converts $p$ NPG (substrate) to $p$-nitrophenol ( $p$ NP) and is measured spectrophotometrically at $410 \mathrm{~nm}$ wavelength. Initially, a mixture containing $75 \mu \mathrm{l}$ of $\alpha-$ glucosidase $(2.5 \mathrm{U} / \mathrm{ml}), 100 \mu \mathrm{l}$ of algal extract or $100 \mu \mathrm{l}$ of $0.1 \mathrm{M}$ phosphate buffer $\mathrm{pH} 6.8$ (for the case of the control) were mixed in sterile test tubes. The total volume of the mixture was adjusted to $500 \mu \mathrm{l}$ by adding $30 \mu 1$ of $10 \mathrm{mM}$ p-nitrophenyl- $\alpha$-D-glucopyranoside (Sigma N1337) and 295 $\mu$ l buffer before incubation. The mixtures were then incubated at $37^{\circ} \mathrm{C}$ for 12 minutes after which $3 \mathrm{~mL}$ of $50 \mathrm{mM} \mathrm{NaOH}$ were added in the mixture [6,10]. Absorbance reading of each reaction mixtures (samples) was taken at $410 \mathrm{~nm}$. The percent $\alpha$-glucosidase inhibition was determine using the equation below:

$$
\alpha-\text { Glucosidase Inhibition }(\%)=\left(\frac{A_{\text {control }}-A_{\text {sample }}}{A_{\text {control }}}\right) \times 100
$$

\section{Statistical Analyses}

The data obtained from the experiments are given as means \pm standard deviations (mean $\pm \mathrm{SD}$ ) of three replicates [2]. In addition, correlation analysis was done using MS Office Excel 2017. 


\section{RESULT AND DISCUSSION}

\section{Total Phenolic Content and Antioxidant Activity}

Bioactive compounds from cyanobacteria such as carotenoids, polyunsaturated fatty acids, mycosporine-like amino acids (MAAs), phenolic compounds, and polysaccharides are known potent antioxidants [11]. However, limited reports are available on the antioxidant properties, identification, and quantification of these compounds and its important role in the algal defense against exposure to high concentration of reactive oxygen species (ROS) [12]. Polyphenols are secondary metabolites found in several cyanobacterial species which can be tapped nowadays for pharmaceutical application because of the reported potent antioxidant, antibacterial, and antidiabetic properties $[11,12,13]$. The TPC of $C$. minutus is $11.27 \pm 0.14 \mathrm{mg} \mathrm{GAE} / \mathrm{g}$ extract. This result was greater than those observed from other cyanobacteria such as Lyngbya sp., Oscillatoria sp., Spirulina sp., and Microcystis sp. with TPC of 5.02 $\pm 0.20,2.96 \pm 0.14,1.78 \pm 0.07$, and $2.65 \pm 0.14 \mathrm{mg} \mathrm{GAE} / \mathrm{g}$, respectively [13]. However, Singh et al. [14] reported that cell-free extract of Anabaena dolium, Calothrix geitonos, Oscillatoria ocuta, and Nostoc ellipsosporum have higher TPC than $C$. minutus, which are $47.77 \pm 3.4,22.80 \pm 2.3,290.23 \pm$ 2.2 , and $39.03 \pm 1.8 \mathrm{mg} \mathrm{GAE} / \mathrm{g}$, respectively. In general, variations in the amount of phenolic compounds in the cyanobacterial extract is dependent on the extraction protocol, type and polarity of solvent used in the extraction as well as solubility of algal polyphenols in the extraction solvents $[11,12]$.

Table 2. DPPH radical scavenging activity and $\mathrm{IC}_{50}$ value of Chroococcus minutus extract and ascorbic acid

\begin{tabular}{|c|c|c|c|}
\hline \multicolumn{2}{|c|}{ Chroococcus minutus } & \multicolumn{2}{|c|}{ Ascorbic Acid } \\
\hline $\begin{array}{c}\text { Phenolic } \\
\text { concentration } \\
(\mu \mathrm{g} \mathrm{GAE} / \mathrm{ml})\end{array}$ & $\begin{array}{c}\mathrm{DPPH}^{+} \text {Inhibition } \\
(\%)\end{array}$ & $\begin{array}{l}\text { Concentration } \\
(\mu \mathrm{g} / \mathrm{ml})\end{array}$ & $\begin{array}{c}\mathrm{DPPH}^{+} \text {Inhibition } \\
(\%)\end{array}$ \\
\hline 100 & $30.28 \pm 0.21$ & 100 & $18.86 \pm 0.21$ \\
\hline 200 & $43.97 \pm 0.84$ & 200 & $38.12 \pm 0.37$ \\
\hline 300 & $55.02 \pm 0.58$ & 300 & $57.16 \pm 0.42$ \\
\hline 400 & $62.69 \pm 1.10$ & 400 & $76.43 \pm 0.89$ \\
\hline 500 & $71.32 \pm 0.05$ & 500 & $91.35 \pm 0.37$ \\
\hline $\mathrm{IC}_{50}$ * & $255 \mu \mathrm{g} / \mathrm{ml}$ & $\mathrm{IC}_{50}$ * & $262 \mu \mathrm{g} / \mathrm{ml}$ \\
\hline
\end{tabular}

$* \mathrm{IC}_{50}$ is the effective concentration that inhibits the activity of DPPH radical by $50 \%$. Computed by interpolation.

Phenolic compounds derived from cyanobacteria are potent free radical scavengers. These compounds are capable of scavenging DPPH by donation of electron or hydrogen atom provision. Phenolic compounds transform DPPH into a colorless product (2, 2-diphenyl-1- hydrazine), causing a decrease in optical density of the sample extract [15]. The antioxidant activity of $C$. minutus extract was evaluated using the DPPH radical scavenging assay. Results showed that the activity against DPPH free radicals increased when the concentration of C. minutus extract (100 - 500 $\mu \mathrm{g} / \mathrm{ml})$ increases (Table 2). The $\mathrm{IC}_{50}$ value of the cyanobacterial extract $(255 \mu \mathrm{g} / \mathrm{ml})$ showed a more potent antioxidant activity than 
that obtained from the control antioxidant, ascorbic acid with $\mathrm{IC}_{50}$ of $262 \mu \mathrm{g} / \mathrm{ml}$. The antioxidant activity of $C$. minutus is considered more effective than those obtained from other species of cyanobacteria such as Calothrix brevissima, Westiellopsis prolifica, Scytonema simplex, and Anabaena constricta with $\mathrm{IC}_{50}$ value of $2.24 \pm 0.18,3.52 \pm 0.26,1.42 \pm 0.19$, and $0.91 \pm 0.04 \mathrm{mg} / \mathrm{ml}$, respectively [14]. Antioxidant activity of cyanobacteria may be associated to several polyphenols (such as gallic acids, vanillic acids, quercetin, ferulic acids, kaempferol, and rutin) present in C. minutus extract. These active substances are reported to have potent free radical scavenging ability [14]. In addition, factors such as strains of the cyanobacteria and culture growth conditions may also show an important effect on the amount and profile of phenolic compounds (in the extract) and thus affecting the antioxidant activity of the algal extract $[2,14]$.

\section{Antibacterial Activity}

Cyanobacteria are good sources of active metabolites with potent antimicrobial activities. These reported antimicrobial activities are associated with various intracellular and extracellular metabolites that are produced by several strains of this group of cyanobacteria with known diverse biological activities [16,17]. Chroococcus minutus exhibited antibacterial activities against known pathogenic bacteria (Methicillin-resistant Staphylococcus aureus (MRSA), Bacillus cereus and Listeria monocytogenes) (Table 3). The antibacterial property of $C$. minutus extract against B. cereus and $L$. monocytogenes is comparable to those observed from extracts of Moorea producens which exhibited minimum inhibitory concentration (MIC) value of $250 \mu \mathrm{g} / \mathrm{ml}$ for both bacterial pathogens [18]. In addition, C. minutus extract exhibited effective antibacterial activity against MRSA like that of Nostoc sp. with reported MIC value of $0.8 \mu \mathrm{g} / \mathrm{ml}$ [19]. The antibacterial activity exhibited by C. minutus in this study may be associated to known secondary metabolites in cyanobacteria such as gallic acids, quercetin, ferulic acids, and kaempferol which are toxic to several microorganisms such as bacteria [16,19]. The study also reported that $C$. minutus extract did not exhibit antibacterial activities against Gram-negative bacteria (Table 3). In general, C. minutus extract is more effective in Gram-positive than Gram-negative bacteria. These differences in the antibacterial activities may be associated with a multilayered structure of cell wall in Gram-negative bacteria that serve as additional barrier that protects the bacterial cells from bioactive compounds present in the algal extract [20].

\section{$\alpha$-Glucosidase Inhibition Activity}

Diabetes is a metabolic disease characterized by having high concentration of glucose in blood [21]. The management of this metabolic disorder is done by lowering the postprandial increase in blood glucose levels via inhibition of important carbohydrate-degrading enzyme ( $\alpha$-glucosidase), responsible for the breakdown of complex carbohydrates into glucose [22]. In this study, evaluation of the potential antidiabetic activity of $C$. minutus was done in vitro via $\alpha$-glucosidase inhibition assay. The inhibitory activity of $C$. minutus extract on the target enzyme is presented in Table 4. The algal extract exhibited a 
concentration-dependent reduction in $\alpha$-glucosidase inhibition. $C$. minutus extract exhibited the highest inhibition of $\alpha$-glucosidase $(91.29 \pm 0.05 \%)$ at phenolic extract concentration of $8 \mu \mathrm{g} \mathrm{GAE} / \mathrm{ml}$. $C$. minutus extract has potent $\alpha$-glucosidase inhibition property ( $\mathrm{IC}_{50}$ of $5.5 \mu \mathrm{g} / \mathrm{ml}$ ) - more effective than acarbose ( $\mathrm{IC}_{50}$ of $6771 \mu \mathrm{g} / \mathrm{ml}$ ) which is a known standard antidiabetic drug. The $\mathrm{IC}_{50}$ value of $C$. minutus extract against $\alpha$-glucosidase is comparable to that observed for methanolic extract of Arthrospira platensis and Cylindrospermum sp. with $\mathrm{IC}_{50}$ values of $145 \mu \mathrm{g} / \mathrm{ml}$ and $84 \pm 6.8 \mathrm{nM}$, respectively [23,24]. The antidiabetic properties of cyanobacteria can be attributed to bioactive substances such as phenolic compounds, pigments, and polysaccharides that are reported to possess $\alpha$-glucosidase inhibitory activity $[25,26,27]$. These compounds are known inhibitors of hydrogen ion (via hydrogen scavenging mechanism) that is being discharged from the active site of the target enzyme ( $\alpha$-glucosidase) [6,26,27]. In conclusion, Chroococcus minutus extract exhibited promising bioactivities such as antioxidant, antibacterial, and alpha-glucosidase inhibition properties that can be used for pharmaceutical application. It is recommended that additional studies should be done to identify the bioactive compounds present in the cyanobacterial extract. Also, in vivo experimental trials should be conducted to confirm the effectivity and assess the safety of $C$. minutus extract for future medical application.

Table 3. Antibacterial activities of Chroococcus minutus extract

\begin{tabular}{|l|l|}
\hline Bacterial Pathogen & Antibacterial Activity \\
\hline Gram-positive bacteria & \\
\hline $\begin{array}{l}\text { Bacillus cereus } \\
\text { BIOTECH } 1509\end{array}$ & ++++ \\
\hline $\begin{array}{l}\text { Listeria monocytogenes } \\
\text { BIOTECH } 1958\end{array}$ & ++++ \\
\hline $\begin{array}{l}\text { Methicillin-Resistant Staphylococcus aureus } \\
\text { BIOTECH } 10378\end{array}$ & +++ \\
\hline Gram-negative bacteria & ND \\
\hline $\begin{array}{l}\text { Pseudomonas aeruginosa } \\
\text { BIOTECH 1824 }\end{array}$ & ND \\
\hline $\begin{array}{l}\text { Aeromonas hydrophila } \\
\text { BIOTECH } 10089\end{array}$ & ND \\
\hline $\begin{array}{l}\text { Escherichia coli } \\
\text { BIOTECH 1825 }\end{array}$ & $\begin{array}{l}*+=\text { full crude extract concentration; }+++=\frac{1}{2} \text { of crude extract concentration; }++++\frac{1}{4} \text { of crude extract } \\
\text { concentration; }++++=\frac{1}{8} \text { of crude extract concentration; ND }=\text { None Detected. }\end{array}$ \\
\hline
\end{tabular}


Table 4. Alpha-glucosidase inhibition activity and $\mathrm{IC}_{50}$ value of Chroococcus minutus extract and acarbose

\begin{tabular}{|c|c|c|c|}
\hline \multicolumn{2}{|c|}{ Chroococcus minutus } & \multicolumn{2}{c|}{ Acarbose** $^{*}$} \\
\hline $\begin{array}{c}\text { Phenolic } \\
\text { concentration } \\
\mu \mathrm{g} \text { GAE/ml })\end{array}$ & $\begin{array}{c}\text { Alpha-glucosidase } \\
\text { Inhibition }(\%)\end{array}$ & $\begin{array}{c}\text { Concentration } \\
(\mu \mathrm{g} / \mathrm{ml})\end{array}$ & $\begin{array}{c}\text { Alpha-glucosidase } \\
\text { Inhibition }(\%)\end{array}$ \\
\hline 4 & $13.73 \pm 0.72$ & 2000 & $17.96 \pm 1.36$ \\
\hline 5 & $34.10 \pm 1.34$ & 4000 & $31.69 \pm 1.22$ \\
\hline 6 & $67.90 \pm 0.91$ & 6000 & $45.32 \pm 1.90$ \\
\hline 7 & $83.08 \pm 2.25$ & 8000 & $57.26 \pm 0.49$ \\
\hline 8 & $91.29 \pm 0.05$ & 10000 & $62.35 \pm 0.49$ \\
\hline $\mathbf{I C}_{\mathbf{5 0}}{ }^{*}$ & $\mathbf{5 . 5} \boldsymbol{\mu g} / \mathbf{m l}$ & $\mathbf{I C}_{\mathbf{5 0}}{ }^{*}$ & $\mathbf{6 7 7 1} \boldsymbol{\mu g} / \mathbf{m l}$ \\
\hline
\end{tabular}

*Inhibitory concentration that inhibits alpha-glucosidase activity by $50 \%$.

***eference alpha-glucosidase inhibitor and anti-diabetic drug.

\section{ACKNOWLEDGEMENT}

The author acknowledges the support given by the PNCM-BIOTECH, UPLB for this research study. The author also is thankful to Mrs. Arsenia B. Sapin (Food Laboratory) for her technical assistance in the conduct of the assays needed in the study.

\section{AUTHOR CONTRIBUTIONS}

Concept: E.D.L.R.A; Design: E.D.L.R.A; Control: E.D.L.R.A; Sources: E.D.L.R.A; Materials: E.D.L.R.A; Data Collection and/or processing: E.D.L.R.A; Analysis and/or interpretation: E.D.L.R.A; Literature review: E.D.L.R.A; Manuscript writing: E.D.L.R.A; Critical review: E.D.L.R.A; Other: E.D.L.R.A.

\section{CONFLICT OF INTEREST}

The author declares no conflict of interest.

\section{ETHICS COMMITTEE APPROVAL}

The author declares that the ethics committee approval is not required for this study. 


\section{REFERENCES}

1. Rao, D. B. (2015). Antibacterial activity of fresh water Cyanobacteria. Journal of Algal Biomass Utilization. 6(3), 60-64. [CrossRef]

2. Arguelles, E.D.L.R. (2021). Biochemical composition and bioactive properties of Chlorella minutissima $(\mathrm{Chm} 1)$ as a potential source of chemical compounds for nutritional feed supplement and disease control in aquaculture. Current Applied Science and Technology, 21(1), 65-77. [CrossRef]

3. Katircioglu, H., Beyalti, Y., Aslim, B., Yusekdag, Z., Atic, T. (2006). Screening for antimicrobial agent production of some microalgae in freshwater. The Internet Journal of Microbiology. 2(2), 63-72. [CrossRef]

4. Ray, S., Bagchi, S.N. (2001). Nutrients and pH regulate algicide accumulation in cultures of the cyanobacterium Oscillatoria laetevirens. The New Phytologist. 149, 455-460. [CrossRef]

5. Li, H.B., Cheng, K.W., Wong, C.C., Fan, K.W., Chen, F., Jiang, Y. (2007). Evaluation of antioxidant capacity and total phenolic content of different fractions of selected microalgae. Food Chemistry, 102, 771-776. [CrossRef]

6. Arguelles, E.D.L.R., Sapin, A., B. (2021). Chemical composition and bioactive properties of Sargassum aquifolium (Turner) C. Agardh and its potential for pharmaceutical application. Philippine Journal of Science, 151(S1), 9-24. [CrossRef]

7. Nuñez Selles, A., Castro, H.T.V., Aguero, J.A., Gonzalez, J.G., Naddeo, F., De Simone, F., Pastrelli, L. (2002). Isolation and quantitative analysis of phenolic antioxidants, free sugars and polyols from mango (Mangifera indica L.) stem bark aqueous decoction used in Cuba as a nutritional supplement. Journal of Agricultural and Food Chemistry, 50, 762-766. [CrossRef]

8. Ribeiro, S.M.R., Barbosa, L.C.A., Queiroz, J.H., Knodler, M., Schieber, A. (2008). Phenolic compounds and antioxidant capacity of Brazilian mango (Mangifera indica L.) varieties. Food Chemistry. 110(3), 620-626. [CrossRef]

9. Arguelles, E.D.L.R., Sapin, A., B. (2020). Bioactive properties of Sargassum siliquosum J. Agardh (Fucales, Ochrophyta) and its potential as source of skin-lightening active ingredient for cosmetic application. Journal of Applied Pharmaceutical Science, 10(7), 51-58. [CrossRef]

10. Nair, S.S., Kavrekar, V., Mishra, A. (2013). In vitro studies on alpha-amylase and alphaglucosidase inhibitory activities of selected plant extracts. European Journal of Experimental Biology, 3(1), 128-132. [CrossRef]

11. Vega, J., Bonomi-Barufi, J., Gomez-Pinchetti, J.L., Figueroa, F.L. (2020). Cyanobacteria and red macroalgae as potential sources of antioxidants and UV radiation-absorbing compounds for cosmeceutical applications. Marine Drugs, 18(12), 659. [CrossRef]

12. Rahul, V., Agrawal, P., Sharma, M., Shukla, S. (2016). Total phenolics, flavonoids, and antioxidant potential of organic extract of freshwater algal sample collected from a marine lake. Indian Journal of Geo-Marine Sciences, 45(10), 1320-1326. [CrossRef] 
13. Hossain, M.F., Ratnayake, R.R., Meearajini, K., Kumara, K.L.W. (2016). Antioxidant properties in some selected cyanobacteria isolated from freshwater bodies of Sri Lanka. Food Science and Nutrition, 4(5), 753-758. [CrossRef]

14. Singh, D.P., Prabha, R., Verma, S., Meena, K.K., Yandegiri, M. (2017). Antioxidant properties and polyphenolic content in terrestrial cyanobacteria. 3 Biotech, 7(2):134. [CrossRef]

15. Liu, N., Fu, X., Duan, D., Xu, J., Gao, X., Zhao, L. (2018). Evaluation of bioactivity of phenolic compounds from the brown seaweed of Sargassum fusiforme and development of their stable emulsion. Journal of Applied Phycology, 30, 1955-1970. [CrossRef]

16. Arguelles, E.D.L.R., Laurena, A.C., Martinez-Goss, M.R. and Monsalud, R.G. (2017). Antibacterial activity, total phenolic content and antioxidant capacity of a green microalga Desmodesmus sp. (U-AU2) from Los Baños, Laguna (Philippines). Journal of Nature Studies, 16(2), 1-13. [CrossRef]

17. Charoonnart, P., Purton, S., Saksmerprome, V. (2018). Applications of microalgal biotechnology for disease control in aquaculture. Biology, 7(2), 24. [CrossRef]

18. Dussault, D., Vu, K.D., Vansach, T., Horgen, F.D., Lacroix, M. (2016). Antimicrobial effects of marine algal extracts and cyanobacterial pure compounds against five foodborne pathogens. Food Chemistry, 199, 114-118. [CrossRef]

19. Preisitsch, M., Harmrolfs, K., Vansach, T., Pham, H.T.L., Heiden, S.E., Füssel, A., Wiesner, C., Pretsch, A., Swiatecka-Hagenbruch, M., Niedermeyer, T.H.J., Müller, R., Mundt, S. (2015). Anti-MRSA-acting carbamidocyclophanes $\mathrm{H}-\mathrm{L}$ from the Vietnamese cyanobacterium Nostoc sp. CAVN2. The Journal of Antibiotics, 68, 165-177. [CrossRef]

20. Arguelles, E.D.L.R. (2018). Proximate analysis, antibacterial activity, total phenolic content and antioxidant capacity of a green microalga Scenedesmus quadricauda (Turpin) Brébisson. Asian Journal of Microbiology Biotechnology and Environmental Science, 20(1), 150-158. [CrossRef]

21. Priatni, S., Budiwati, T.A., Ratnaningrum, D., Kosasih, W., Andryani, R., Susanti, H., Susilaningsih, D. (2016). Antidiabetic screening of some Indonesian marine cyanobacteria collection. Biodiversitas, 17(2), 642-646. [CrossRef]

22. Ghosh, T., Bhayani, K., Paliwal, C., Maurya, R., Chokshi, K., Pancha, I., Mishra, S. (2016). Cyanobacterial Pigments as Natural Anti-Hyperglycemic Agents: An In vitro Study. Frontiers in Maine Science, 3, 146. doi: 10.3389/fmars.2016.00146. [CrossRef]

23. Jüttner, F., Wessel, H.P. (2003). Isolation of Di(Hydroxymethyl)Dihydroxypyrrolidine from the cyanobacterial Genus Cylindrospermum that effectively inhibits digestive glucosidases of aquatic insects and crustacean grazers. Journal of Phycology, 39, 26-32. [CrossRef]

24. Gouda, K.G.M., Kavitha, M.D., Sarada, R. (2015). Antihyperglycemic, Antioxidant and antimicrobial activities of the butanol extract from Spirulina platensis: antihyperglycemic effect of Spirulina. Journal of Food Biochemistry, 39, 594-602. [CrossRef]

25. Gradíssimo, D.G., Oliveira da Silva, V.C., Xavier, L.P., do Nascimento, S.V., Valadares, R.B.d.S., Faustino, S.M.M., Schneider, M.P.C., Santos, A.V. (2021). Glucosidase inhibitors screening in microalgae and cyanobacteria isolated from the amazon and proteomic analysis of inhibitor producing Synechococcus sp. GFB01. Microorganisms, 9, 1593. [CrossRef] 
26. Kim K-T, Rioux L-E, Turgeon SL. (2014). Alpha-amylase and alpha-glucosidase inhibition is differentially modulated by fucoidan obtained from Fucus vesiculosus and Ascophyllum nodosum. Phytochemistry, 98, 27-33. [CrossRef]

27. Arguelles E.D.L.R., Sapin, A.B. (2020). In vitro antioxidant, alpha-glucosidase inhibition, and antibacterial properties of Turbinaria decurrens Bory (Sargassaceae, Ochrophyta). Asia-Pacific Journal of Science and Technology, 25(3). [CrossRef] 